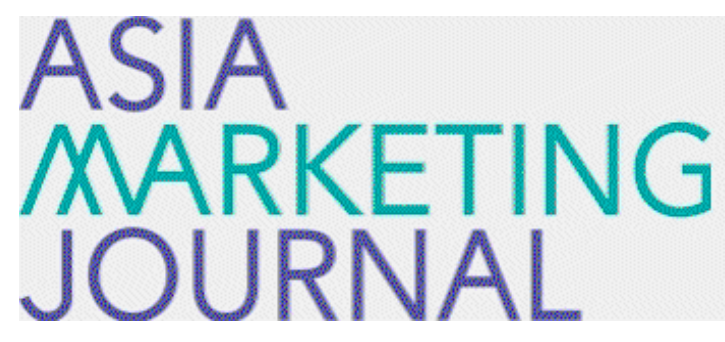

ASIA MARKETING JOURNAL

Volume 22 | Issue 4

Article 1

$1-31-2021$

\title{
Who Buys Our Brand? The Influence of Consumption Values and the Congruity with Brand Benefits on Brand Identification, Trust and Loyalty
}

Sol Namkung

Seong-Yeon Park

Follow this and additional works at: https://amj.kma.re.kr/journal

Part of the Marketing Commons

\section{Recommended Citation}

Namkung, Sol and Park, Seong-Yeon (2021) "Who Buys Our Brand? The Influence of Consumption Values and the Congruity with Brand Benefits on Brand Identification, Trust and Loyalty," Asia Marketing Journal: Vol. 22 : Iss. 4 , Article 1.

Available at: https://doi.org/10.15830/amj.2020.22.4.1

This Article is brought to you for free and open access by Asia Marketing Journal. It has been accepted for inclusion in Asia Marketing Journal by an authorized editor of Asia Marketing Journal. 


\title{
Who Buys Our Brand? The Influence of Consumption Values and the Congruity with Brand Benefits on Brand Identification, Trust and Loyalty*
}

\author{
Sol Namkung** \\ Seong-Yeon Park ${ }^{* * *}$
}

\begin{abstract}
This paper explores how the positive effect achieved when consumption value matches brand benefit can increase brand loyalty. Prior research on consumption value mainly focused on perceived value; these studies omit consumers' views of consumption value. Therefore, this study examines the effect of congruence between consumption values (functional, emotional, social, and ethical value) and perceived brand benefits (enabling, enticing, symbolic, and socially responsible benefits) on consumers' brand identification, trust, and loyalty. We find a positive effect on brand identification and brand trust when a consumer's value is similar to a brand benefit, particularly between functional value and enabling benefit, and ethical value and socially responsible benefit. However, congruence between consumption value and perceived brand benefit only had an indirect effect on brand loyalty by mediating brand identification and trust. This study provides a basis for implementing a marketing strategy to build brand assets and increase brand loyalty by providing consumers with the value they want in a diversified market.
\end{abstract}

Keywords: consumption value, perceived brand benefit, brand identification, brand trust, brand loyalty, consumer behavior

\section{Introduction}

In 2020, as the global economic situation deteriorated because of COVID-19, local governments promoted a "good consumption movement" to revitalize local economies and save local markets (Regional Regulatory Innovation

* This article is an extended and edited version of the first author Sol Namkung's 2020 master's thesis

** Graduate Student, School of Business, Ewha Womans University (nks1552@gmail.com)

*** PhD, Professor of Marketing, School of Business Ewha Womans University (sypark@ewha.ac.kr), Corresponding Author 
Division, 2020). They introduced various ways to promote consumption, such as prepayments for small business owners and direct purchase of agricultural products for farmers and fishermen. Good consumption refers to the phenomenon of purchasing goods or services based on their impact on the environment and society (MBN, n.d.). Its meaning is similar to expressions like good priority, acting first to create good changes in the world; fair player, a tendency to value fairness by evaluating the morality of a brand in terms of consumption; must be green, indicating that eco-friendly is no longer just an option; and meaning out, expressing an individual's characteristics and political and social beliefs (Kim et al., 2017, 2018, 2019; University Tomorrow 20’s Lab, 2019). In a survey of perceptions of value consumption, $78.1 \%$ responded that "people wish to participate in the good consumption movement even when buying one product" has increased and 70.5\% responded that "if I helped someone through my consumption, I am happy enough" (Embrain Trend Monitor, 2019). In other words, consumers express their opinions through their consumption. They tend to buy products or brands that meet their beliefs or values regardless of the price, while boycotting products or companies that are contrary to their beliefs and values.

We are living in a Market 3.0 era, which can be described as value driven. Unlike in Market 2.0, when consumption-oriented functions and emotions were pursued, consumers in Market
3.0 tend to pursue their own values (Kotler et al., 2010). Consumers in this era buy brands that reflect their value even if that means they pay more. Embrain Trend Monitor (2019) found that $64.4 \%$ of respondents were willing to participate in good consumption activities and more than 50\% were willing to pay extra for their value and identity. For example, upcycling brand Freitag makes and sells bags made of truck tarpaulins, car seat belts, and bicycle rubber tubes that are more than 5 years old (Freitag, n.d.). Despite the expensive price, sales are increasing because people who are interested in the eco-friendly movement, believe this bag can express their value of conscious consumption. In modern society, Market 3.0 consumers express their values by choosing brands that can satisfy their values. Therefore, consumption values are very important today. However, previous studies of consumption value have mainly examined the perceived value of a brand rather than the consumption values held by consumers. Therefore, these studies of consumption values are insufficient (Koo et al., 2015).

In addition, consumers in Market 3.0 regard morality and ethics as important values because they are human beings with personality, reason, and emotion (Kotler, 2010). Previous studies are limited by not including ethical values as components of consumption value. Therefore, the purpose of this study is to illustrate the effect of a consumer's perception that a brand's benefits matches their consumption values on 
brand identification, brand trust, and brand loyalty. It selects functional value, emotional value, social value, and ethical value as aspects of consumption value, and uses the consumption value theory of Sheth et al. (1991) and Holbrook (2006) to understand and predict contemporary consumers.

\section{Theoretical Background}

\subsection{Consumption Value}

The concept of consumption value is based on the concept of general value, which can be defined as an individual's beliefs about direct actions and judgments about the ultimate goal of existence. It applies across many situations and can be defined as a broad concept that shapes attitudes and behaviors (Rokeach, 1979; Koo et al., 2015, Park, 2018). If general value is the standard that controls one's entire life, consumption value is a criterion and belief that affects how one judges and acts as a consumer in that area of life (Koo et al., 2015).

Early research in economics on consumption value defined it as a consumer's evaluation of economic utility based on the payment and the gains obtained from the purchase (Zeithaml, 1988). Since then, a multidimensional approach has considered noneconomic aspects. Among the several studies that attempted a multidimensional approach to consumption value, Sheth et al. (1991) and Holbrook (1999) provided the most common theoretical framework.

Sheth et al. (1991) proposed a theory in which consumption value consists of functional value, social value, emotional value, epistemic value, and conditional value. Functional value can be related to a product's functional, utilitarian, or physical attributes; that is, the objective attributes that products have. Social value can be defined as a product's association with specific groups, perhaps their demographic or socioeconomic group or a reference group they aspire to. Emotional value means that the product or service prompts feelings or an affective state. Something that provokes curiosity, provides novelty, or satisfies a desire for knowledge has epistemic value. Conditional value is difficult to maintain consistently because of situational changes, so it was excluded from this study. It is considered more of a moderating factor on other values than an independent consumption value (Park \& Kim, 2006; Nam, 2007; Koo et al., 2015; Won \& Chung, 2015; Park, 2018). Based on the characteristics of consumption value, Holbrook (1999) divided consumers into eight types according to three dimensions: extrinsic versus intrinsic, self-oriented versus other-oriented, and active versus reactive. In a follow-up study, Holbrook (2006) reclassified eight types of consumption value into economic value, social value, hedonic value, and altruistic value. Holbrook's economic value, social value, 
and hedonic value are considered to overlap or resemble Sheth et al.'s (1991) functional value, social value, and emotional value (SanchezFernandez et al., 2009; Papista \& Krystallis, 2013: Won \& Chung, 2015; Park, 2018). Because Holbrook's (2006) study contains altruistic value, it is more comprehensive than other studies (Gummerus, 2013; Won \& Chung 2015). However, it is extremely rare to find spirituality, one of the subordinate elements of altruistic value, in studies of consumption value, and follow-up studies are limited by the complexity of Holbrook's classification of consumption value types (Boksberger \& Melsen, 2011; Won \& Chung, 2015).

The consumption values of Sheth et al. (1991) are prominent in studies of consumption value and consumption behavior (Boksberger \& Melsen, 2011; Morar, 2013; Koo et al., 2015). Based on prior research, Koo et al. (2015) classified consumption value into 10 subdimensions: utility oriented, security oriented, low-price oriented, hedonism oriented, aesthetics oriented, innovation oriented, others oriented, community oriented, autonomy oriented, and self-expression oriented. Community-oriented value can be seen as similar to the ethical value that Holbrook includes among the altruistic values.

Based on this previous research, we selected functional value, emotional value, social value, and ethical value as the four types of consumption value that were suitable for this study.

\subsection{Brand Benefit}

Consumers tend to evaluate the benefits provided by a product's attributes before making any purchases. Brand benefits refer to the subjective value consumers place on a product or service (Keller, 1993). In other words, consumers are not only purchasing a product, but also they are purchasing various benefits provided by it that satisfies their desires and expectations.

Holbrook and Hirschman (1982) defined brand benefits as the personal satisfaction that consumers expect from using products or brands. It is comprised of practical, pleasant, and symbolic benefits. Keller (1993) classified these brand benefits into symbolic benefits that promote social approval or personal self-expression, functional benefits related to the intrinsic advantage of the product, experiential benefits from the emotional feelings from using a product or service.

Park et al. (1986) claimed that consumer desire influences product selection. That desire is composed of functional needs, symbolic needs, and experiential needs. Park et al., (2016) argued that brand benefit is not a characteristic of the product; rather, it results from customers meeting their desired goals by purchasing and using the brand. They argued that it is necessary to provide enabling benefits, enticing benefits, and enriching benefits. Enabling benefits refers to a situation where solving problems and saving resources leads to trusting the brand, enticing benefits stimulate the senses and lead 
one to feel love for the brand. Enriching benefits reflect an individual's hopes and beliefs and foster belongingness and distinctiveness, which lead to brand respect.

According to these previous studies, brand benefits can be classified into enabling benefits from the functions or objective qualities of the goods, enticing benefits from feelings when using the goods or service, and enriching benefits from expressing one's belongingness or one's beliefs. However, the enriching benefit proposed by Park et al. (2016) includes two different benefits: symbolic and socially responsible benefits.

Symbolic benefit comes from gaining social approval from a reference group or from selfexpression through the symbolic meaning of the good or service. Socially responsible behavior of a brand is indispensable to get respect and admiration of consumers. It should be emphasized to improve the brand image and a maintain sustainable relationship with consumers beyond business activities (Quaak, Aalbers, \& Goedee, 2007). According to Stenn (2013), consumers who support Fair Trade are often labeled as socially responsible, ethical, green, and ecofriendly. So were the products that were being marketed toward them. Thus, consumers pursuing ethical values prefer to buy products from socially responsible brands.

Therefore, we classify brand benefits into enabling, enticing, symbolic and socially responsible benefits.

\subsection{Congruence Between Consumption Value and Perceived Brand Benefit}

Consumers feel more attractive when their identity corresponds with brand identification and wish to express and maintain their identity through the brand (Bhattacharya \& Sen, 2003). According to the self-image congruence theory, psychological comparisons of self-concepts and brand images influence consumer behavior. These have a high degree of congruence when consumers perceive their identity and brand images as similar (Hamilton \& Sun, 2005; Johar \& Sirgy, 1991).

Congruence between consumer values and perceived brand benefits match the congruence between self-image and brand personality. Brands want to deliver their value and benefits to consumers (Shim, 2019), and consumers want to express their basic needs and goals based on their own consumption values (Won \& Chung, 2015: Park, 2018). Brand benefits enable consumers to meet their needs or goals by purchasing and using the brand (Park et al., 2016). Therefore, value can be an essential connection between consumers and brands that can highly influence consumer behavior (Allen et al., 2002; DeChernatony \& McDonald, 2003).

Brand benefit is an intrinsic attribute that relates to the characteristics of a product or service. It refers to the performance and usefulness of a product (Bloch \& Barros 2011), and also consumers' value in objective characteristics of 
products, such as reliability, durability, and price (Sheth et al., 1991; Hoffmann \& Soyez, 2010). In other words, consumers select a brand after identifying the correspondence between their functional value and a brand's enabling benefits.

The enticing benefit is obtaining joy, excitement, pleasure, and satisfaction that consumers experience through purchasing products or services (Gwinner et al., 1998). Consumers pursue sensory experiences for new or innovative products (Mimouni-Chaabane \& Volle, 2010), which can lead to exploratory actions such as being curious or finding information about trends. Consumers seek to acquire emotional value by making choices that trigger or sustain their emotions, pursue newness and diversity, and obtain satisfaction through novelty or knowledge acquisition (Sheth et al., 1991). Therefore, a consumer's emotional value can be matched with a brand's enticing benefit.

Symbolic benefit refers to the benefit that a brand can provide by reflecting consumers' personal expression, self-esteem, and desire for social approval that are fulfilled by using the product (Aaker, 1996). Consumers value the symbolism of a product and select a brand that expresses themselves or offers belonging or social desirability.

Socially responsible benefit refers to the benefits that a brand can provide by reflecting the consumer's ethical beliefs and hopes. Consumers are aware that their consumption can affect others and therefore want to reveal their ethical beliefs through a brand (Park et al., 2016).

\subsubsection{Brand identification}

The concept of brand identification is based on the social identity theory (Tajfel, 1981). Researchers in the marketing field view brand identification as a feeling of connection that an individual has with a brand and have found that they felt the success or failure of a brand as their own (Badrinarayanan \& Laverie, 2011). Underwood et al. (2001) defined it as a mechanism of emotional association between a brand and consumer and stated that consumers construct their own identity by purchasing from or consuming a brand. Consumer-brand identification refers to "a consumer's psychological state of perceiving, feeling, and valuing his or her belongingness with a brand" (Lam et al., 2012, p.307)

Consumers tend to feel more attractive when they use brands in order to express themselves and maintain their image (Bhattacharya \& Sen, 2003). Yi and Ra (2002) stated that consumers feel that brands can reflect and express their self-concept because they gain a sense of self-definition by consuming certain products or services. Johar and Sirgy's (1991) self-congruity theory views value congruence as being achieved by comparing the value of an object with one's own values as a consumer. It has been claimed that consumer behavior 
results from this psychological comparison of consumer's self-concept and brand image (Hamilton \& Sun, 2005). These psychological comparisons increase consistency when consumers perceive that brand image and their self-image are consistent. The consistency of perceived brand benefit and consumption value is similar to brand personality consistency, which evaluates the brand image. Value is an important element that connects consumers with brands, and it has an important influence on consumer behavior (Allen et al., 2002). The congruence of values between consumers and brands has a positive effect on brand identification, brand attachment, and the quality of the brand relationship (Kressmann et al., 2006; Malar et al., 2011). The effect of value congruity between consumers and brands on brand identification has been studied, and greater degrees of congruity between the consumer and the brand have positive effects on brand identification (Tuskej et al., 2013; Elbedweihy et al., 2016).

Congruence of consumer values and perceived brand benefits are be said to be the similarity between a consumer's personal values and their perception of brand value (Edwards \& Cale, 2009). As consumers have different perceptions of brand benefits, which are the value delivered by a brand according to the functional, emotional, social, and ethical values that are elements of their consumption value, the following hypotheses were established regarding how the brand could influence its identification according to its correspondence with enabling, enticing, symbolic, and socially responsible benefits.

H1: The congruence between a consumer's value and a brand benefit positively influences brand identification.

H1a: The congruence between a consumer's functional value and perceived enabling benefit of a brand positively influences brand identification.

H1b: The congruence between a consumer's emotional value and perceived enticing benefit of a brand positively influences brand identification.

H1c: The congruence between a consumer's social value and perceived symbolic benefit of a brand positively influences brand identification.

H1d: The congruence between a consumer's ethical value and perceived socially responsible benefit of a brand positively influences brand identification.

\subsubsection{Brand Trust}

Trust is an important factor in marketing (Morgan \& Hunt, 1994). Morgan and Hunt (1999) claimed that in relationship marketing, trust and commitment to other organizations increase cooperation with the partner companies and reduce uncertainty. The higher the trust in the partner, the higher the level of engagement and the greater the willingness to actively 
cooperate to maintain and improve the relationship (Choi, 2008). Likewise, it is an important variable in the consumer - brand relationship, and it can be linked to the consumer's willingness to continue and strengthen the relationship with the brand.

Through direct and indirect brand experience, consumers will decide on brand trust by having certainty in their associations, judgments, and attributes of the brand (Choi, 2008). The consumer's overall evaluation of the brand, which is formed based on their brand knowledge and experiences, influences their belief that the brand will continuously create value that will satisfy them (Morgan \& Hunt, 1994).

Garbarino and Johnson (1999) stated that trust is formed through computational experiences that consider transaction costs and benefits such as brand satisfaction and quality. Choi (2008) claimed that perceived quality affects brand trust. Therefore, the consumer evaluates the benefits provided by the brand based on their brand experience. In this study, the following hypotheses were established regarding how the correspondence between one's consumption value and perceived brand benefit will influence the degree of brand trust.

H2: The congruence between a consumer's value and a brand benefit positively influences brand trust.

H2a: The congruence between a consumer's functional value and perceived enabling benefit of a brand positively influences brand trust.

H2b: The congruence between a consumer's emotional value and perceived enticing benefit of a brand positively influences brand trust.

H2c: The congruence between a consumer's social value and perceived symbolic benefit of a brand positively influences brand trust.

H2d: The congruence between a consumer's ethical value and perceived socially responsible benefit of a brand positively influences brand trust.

\subsubsection{Brand loyalty}

Consumption value has been studied as a variable that has an important influence on consumer behavior. Consumers purchase to express their goals and desires. They are more attracted to a brand and tend to make repeat purchases when the benefit provided by a brand matches their consumption value (Elbedweihy et al., 2016).

Consumers engage in the psychological commitment of purchasing behavior when a brand matches their ideal self-concept and the frequency of repurchases increases (Nam et al., 2011). In other words, a consumer's interaction with the brand becomes active when they select a brand that matches themselves (Aaker, 1997). Kim et al. (2005) suggested that through 
self-connection, it is possible to form an attachment with a brand and develop a longterm bond with it. Park and Lee (2009) stated that as more consumers feel they are consistent with a brand, they develop affinity for the brand, repurchase products, and recommend the brand to others.

The benefits offered by a brand also have a positive impact on brand loyalty. Shim (2019) empirically identified that the professional, symbolic, and emotional benefits of a brand influence brand loyalty by forming a consumer's attachment to the brand. Meanwhile, Sirgy (1982) argued that consumers who perceive a high correspondence between the image of a product and their self-images are motivated to purchase and consume the product. Given this congruence between consumption values and perceived brand benefits, the following hypotheses were established regarding consumers' preference for brands that match their consumption values and perceived brand benefits, which could ultimately lead to repeated purchases of the product.

H3: The congruence between a consumer's value and a brand benefit positively influences brand loyalty.

H3a: The congruence between a consumer's functional value and perceived enabling benefit of a brand positively influences brand loyalty.

H3b: The congruence between a consumer's emotional value and perceived enticing benefit of a brand positively influences brand loyalty.

H3c: The congruence between a consumer's social value and perceived symbolic benefit of a brand positively influences brand loyalty.

H3d: The congruence between a consumer's ethical value and perceived socially responsible benefit of a brand positively influences brand loyalty.

\subsection{Brand Identification and Brand Trust}

Brand trust is a relationship that is formed from interaction, similar to a relationship between people. Brand trust consists of cognitive and emotional beliefs (Delgado-Ballester et al., 2003; Arnott et al., 2007: Becerra \& Badrinarayanan, 2013). Cognitive brand trust is based on brand consistency, competence, and predictability of performance by objective evaluation of the brand (Chaudhuri \& Holbrook, 2001; DelgadoBallester et al., 2003; Becerra \& Korgaonkar, 2011). Brand trust can also be affected by emotional elements such as integrity, honesty, and benevolence. Choi (2008) stated that trust is influenced by emotional processes, not by simple cognitive information processing.

Brand identification is a crucial emotional bonding mechanism between a consumer and a brand (Yi \& La, 2002; Park \& Lee, 2009). Brand identification is conceptually related 
to the concept of brand trust. On the one hand, trust is an antecedent of an identified relationship, because consumers tend to identify themselves with trustworthy brand to express their self-definition or enhance self-esteem (Keh \& Xie, 2009). On the other hand, brand identification can lead to trust (Williams, 2001; Dunn \& Schweitzer, 2005). Lam et al. (2012) stated that there are calculative trust and identification-based trust. Brand trust in marketing is calculative because it is formed by the consumer's knowledge or objective evaluation about the brand. However, identification-based trust that is subjectively formed in favor of the identified social identity is automatically motivated through identification with the social entity, rather than through experienced benefits (Brewer, 1979; Kramer et al., 1996).

Based on previous research, we can infer that congruity of consumption value with perceived brand benefit not only has direct effect on calculative trust, but also identificationbased trust through brand identification. Thus, the following hypothesis was proposed.

H4: Brand identification positively influences brand trust.

\subsection{Brand Identification and Brand Loyalty}

Consumers communicate with others through the process of purchasing products or services.
They feel a sense of unity with brands that reflect and express themselves well in these processes, so their preference for those brands increases (Keller, 1993).

In regard to the influence of brand identification on brand loyalty, various results have been found. Some studies have shown that brand identification has important effects on brand loyalty (Yi \& Ra, 2002; Kuenzel \& Halliday, 2008; Bang et al., 2010; Stokburger-Sauer et al., 2012; Martinez \& Rodríguez del Bosque, 2013; Lee \& Jeong, 2016), but others have claimed that brand identification has no relation to brand loyalty (Kim et al., 2001; Bagozzi \& Dholakia, 2006; Elbedweigy et al., 2016). However, in He and Li's (2011) research, even though brand identification did not affect brand loyalty directly, there was an indirect effect through customer satisfaction. According to Lee and Jeong (2016), prior studies that revealed the outcome variables of perception on brand identification have shown that when consumers perceive brand identification, the preference for and satisfaction with the brand increases. This promoted the frequency of brand usage and emotional bonds that resulted in high brand loyalty.

Although there are mixed claims about the effect of brand identification on brand loyalty because consumers want to purchase a brand they can use to express themselves (Ahearne et al., 2005), the following hypothesis was established regarding how brand identification 
will influence brand loyalty.

\section{H5: Brand identification positively influences brand loyalty.}

\subsection{Brand Trust and Brand Loyalty}

Research on the consumer - brand relationship has emerged as an important field in brand marketing. Once consumers feel a deep relationship with a brand, higher levels of commitment and loyalty are generated (Yi \& Ra, 2002; Park \& Lee, 2005; Park \& Lee, 2006; Allen et al., 2008; Fournier, 2009). Research on the consumerbrand relationship has claimed that the higher the relationship level, the lower the willingness of consumers to leave the relationship (Fournier, 1998; Chaudihuri \& Holbrook, 2001; Park \& Yu, 2003; Choi \& Cho, 2005; Smit et al., 2007). Brand trust includes consumers' belief that the brand is safe, as well as subjective feelings of reliance on the brand (Khamitov, Wang, \& Thomson, 2019). Chaundhuri and Holbrook (2001) stated that brand trust is a decisive factor in determining brand loyalty. DelgadoBallester and Munuera-Alemán (2005) also argued that trust has a decisive role in forming the highest relationship status between consumers and brands: bonding. Brand trust increases brand loyalty and commitment because it places high value on exchange relationships (Morgan \& Hunt, 1994). Also, brand trust can affect consumers' intentions in online purchasing (Becerra \& Korgaonkar, 2011). Brand recommendation is possible when there is confidence that the brand will meet their expectations (Reichheld, 2003).

Therefore, in this study, the following hypothesis was established regarding how brand trust, formed based on a consumer's cognitive and emotional attitude, affects brand loyalty, which can be stated as the result of a brand relationship.

H6: Brand trust positively influences brand loyalty.

\section{Methodology}

\subsection{Data Collection}

A survey was conducted using online and offline questionnaires via consumer research panel services to people aged 20 - 59 who had preferred fashion brands for purchases. A total of 403 respondents participated in the survey; because there were no missing data or insincere responses, all were used for analysis.

In the sample, $49.9 \%$ were male, ages ranged between 20 - 59 years, and 73.2\% had a university education (bachelor's degree or above). The largest age group was people aged $25-29$ $(23.8 \%)$. Most respondents had graduated from university $(65 \%)$, followed by attended 


\section{〈Figure 1〉Research Model}

\section{Congruence between \\ Consumption Value and \\ Perceived Brand Benefit}

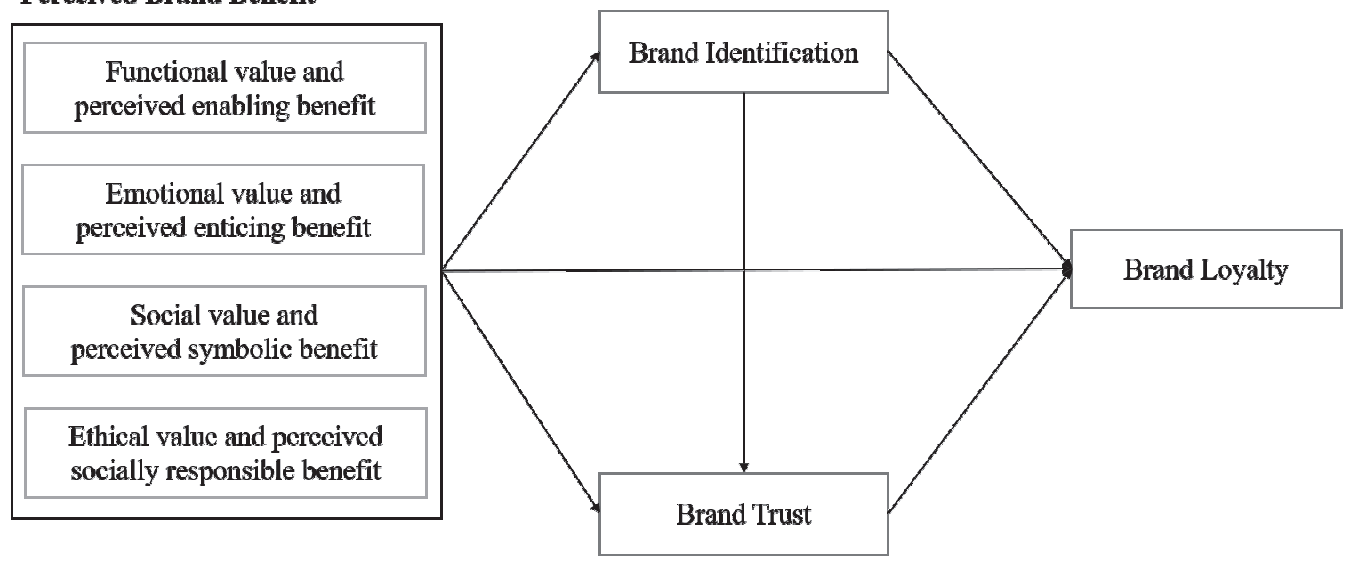

university (12.4\%), high school graduates or less $(12.4 \%)$, and graduate school or higher (8.2\%). In addition, $57.8 \%$ of respondents were office workers, followed by students (14.9\%), professionals $(10.2 \%)$, homeworkers $(8.9 \%)$, self-employed (5.2\%), and others. The largest cohort of monthly standard income level was between two million won and four million South Korean won per household.

\subsection{Measures and measurement model}

The questionnaire examined the effects of consumption value, perceived brand benefit, brand identification, brand trust, and brand loyalty. To measure congruence between consumption value and perceived brand benefit, consumption value was presented first. Then, respondents were asked about the fashion brands they had purchased more than twice within the last six months. Next, they were asked about the benefits of the brand that they had answered.

For consumption value and perceived brand benefit, we adopted 24 modified items from previous research (Chaudhuri \& Holbrook, 2001; Sweeney \& Soutar, 2001; Escalas \& Bettman, 2003; Nam, 2007; Park et al., 2010; Koo et al., 2015). Consumption value consisted of functional, emotional, social, and ethical value items. Brand benefit consisted of enabling, enticing, symbolic, and socially responsible benefits. Brand identification was measured using five modified items from related studies ( Yi \& La, 2002; Lee, 2005; Seo, 2016). Three modified items about brand trust were supplemented by Chaudhuri and Holbrook (2001). For brand loyalty, we adopted five modified items from Chaudhuri and Holbrook (2001). All items were measured on a 7-point Likert scale, ranging from 1 as "strongly disagree" to 7 as "strongly 
agree." The data were analyzed through an exploratory and confirmatory factor analyses, reliability test, and structural equation modeling analysis.

Sirgy's (1982) absolute difference model was used to measure congruence between consumption value and perceived brand benefit. There are various methods for measuring congruence, such as the simple difference model, absolute difference model, and Euclidean distance model. The absolute difference model is simple to calculate and has a higher $\beta$ coefficient; there is no significant difference with the Euclidean distance model in its predictive power. The equation used is:

$$
\mathrm{VC}=\sum_{i=1}^{n}\left|C V_{i}-B B_{i}\right|
$$

where VC (Value-Congruity) is consistency of consumption value and brand benefits, $\mathrm{CV}_{i}$ is a consumer's consumption value for attribute $i$, and $\mathrm{BB}_{i}$ is a consumer's perceived brand benefit for attribute $I$.

\section{Research Results}

\subsection{Reliability and Validity Tests}

Before the hypotheses were tested, reliability and validity of measures were tested by exploratory and confirmatory factor analyses and Cronbach's alpha test. The exploratory factor analysis (EFA) was conducted to confirm that the items are correctly linked to the respective variables, using Principal Component Analysis and Varimax rotation to simplify the factor loadings. Both KMO (Kaiser-Meyer-Olkin) values of consumption values and perceived brand benefits are larger than 0.9 and factor loadings are greater than 0.6.

As result of exploratory factor analysis, the consumption value was classified into four constructs: functional, emotional, social, and ethical value. Perceived brand benefit was classified into four types: enabling, enticing, symbolic, and socially responsible benefits. The results of reliability test were acceptable with Cronbach's alpha values above 0.7 (Table 1 ). According to confirmatory factor analysis (CFA), all the estimates were statistically significant $(p<.001)$. In general, it can be said that discriminant validity is secured when the AVE value is 0.5 or more and the $\mathrm{CR}$ value is 0.7 or more. In this study, even though the AVE values of social value, brand trust, and brand loyalty were below the reference value, convergent validity was secured at an acceptable level in other factors.

\subsection{Hypotheses Tests}

In order to verify the hypotheses of this study, a structural equation modeling analysis was 
$\langle$ Table 1〉 Confirmatory Factor Analysis and Reliability test

\begin{tabular}{|c|c|c|c|c|}
\hline & Functional value & Emotional value & Social value & Ethical value \\
\hline C.R. & 0.814 & 0.840 & 0.844 & 0.901 \\
\hline AVE & 0.655 & 0.561 & 0.496 & 0.656 \\
\hline \multirow[t]{2}{*}{ Cronbach's $\alpha$} & 0.806 & 0.838 & 0.838 & 0.898 \\
\hline & Enabling benefit & Enticing benefit & Symbolic benefits & $\begin{array}{c}\text { Socially responsible } \\
\text { Benefits }\end{array}$ \\
\hline C.R. & 0.820 & 0.865 & 0.919 & 0.889 \\
\hline AVE & 0.633 & 0.510 & 0.637 & 0.647 \\
\hline \multirow[t]{2}{*}{ Cronbach's $\alpha$} & 0.810 & 0.864 & 0.918 & 0.886 \\
\hline & Brand identification & \multicolumn{2}{|c|}{ Brand trust } & Brand loyalty \\
\hline C.R. & 0.892 & \multicolumn{2}{|c|}{0.761} & 0.759 \\
\hline AVE & 0.597 & \multicolumn{2}{|c|}{0.495} & 0.404 \\
\hline Cronbach's $\alpha$ & 0.890 & \multicolumn{2}{|c|}{0.754} & 0.755 \\
\hline
\end{tabular}

〈Figure 2〉 Structural Equation Modeling Analysis

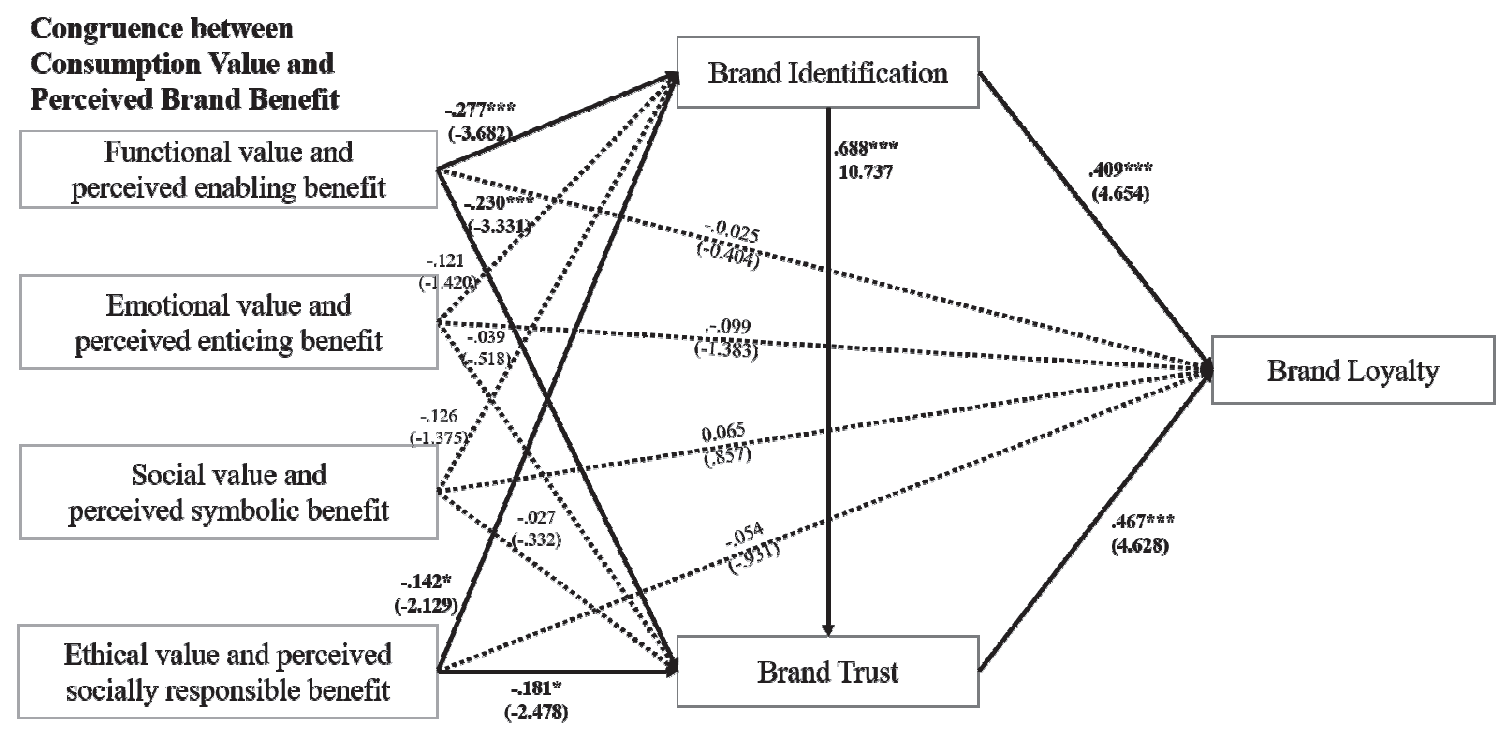

Note. ${ }^{*} \mathrm{p}<.05,{ }^{* *} \mathrm{p}<.01,{ }^{* * *} \mathrm{p}<.001$

performed. The model fit indices were CMIN/ $\mathrm{df}=1.567(\mathrm{p}=0.00), \mathrm{CFI}=0.953, \mathrm{IFI}=$ 0.954, TLI $=0.944$, RMSEA $=0.038$, indicating acceptable structural model fit (Byrne, 2013)
(Table 3). The results are shown in Figure 2. Standardized coefficient estimates were negative because the congruence between consumption value and perceived brand benefit was measured 
〈Table 3〉 Structure Equation Modeling Analysis

\begin{tabular}{|c|c|c|c|c|c|c|}
\hline Independent variables & & $\begin{array}{c}\text { Dependent } \\
\text { variables }\end{array}$ & $\begin{array}{c}\text { Standardized } \\
\text { coefficients }\end{array}$ & S.E. & C.R. & Result \\
\hline $\begin{array}{c}\text { FV \& Enabling benefit } \\
(\mathrm{H} 1 \mathrm{a})\end{array}$ & $\rightarrow$ & \multirow{4}{*}{$\begin{array}{c}\text { Brand } \\
\text { identification }\end{array}$} & -0.277 & 0.253 & $-3.682^{* * *}$ & Supported \\
\hline $\begin{array}{c}\text { EM \& Enticing benefit } \\
(\mathrm{H} 1 \mathrm{~b})\end{array}$ & $\rightarrow$ & & -0.121 & 0.232 & -1.420 & Not Supported \\
\hline $\begin{array}{l}\text { SV \& Symbolic benefit } \\
(\mathrm{H} 1 \mathrm{c})\end{array}$ & $\rightarrow$ & & -0.126 & 0.209 & -1.375 & Not Supported \\
\hline $\begin{array}{c}\text { ETH \& Socially } \\
\text { responsible benefit }(\mathrm{H} 1 \mathrm{~d})\end{array}$ & $\rightarrow$ & & -0.142 & 0.107 & $-2.129^{*}$ & Supported \\
\hline $\begin{array}{c}\mathrm{FV} \& \text { Enabling benefit } \\
(\mathrm{H} 2 \mathrm{a})\end{array}$ & $\rightarrow$ & \multirow{4}{*}{$\begin{array}{l}\text { Brand } \\
\text { trust }\end{array}$} & -0.230 & 0.187 & $-3.331 * * *$ & Supported \\
\hline $\begin{array}{c}\text { EM \& Enticing benefit } \\
(\mathrm{H} 2 \mathrm{~b})\end{array}$ & $\rightarrow$ & & -0.039 & 0.164 & -0.518 & Not Supported \\
\hline $\begin{array}{c}\text { SV \& Symbolic benefit } \\
(\mathrm{H} 2 \mathrm{c})\end{array}$ & $\rightarrow$ & & -0.027 & 0.148 & -0.332 & Not Supported \\
\hline $\begin{array}{c}\text { EV \& Socially responsible } \\
\text { benefit }(\mathrm{H} 2 \mathrm{~d})\end{array}$ & & & 0.126 & 0.077 & $2.090^{*}$ & Supported \\
\hline $\begin{array}{c}\text { FV \& Enabling benefit } \\
(\mathrm{H} 3 \mathrm{a})\end{array}$ & $\rightarrow$ & \multirow{4}{*}{$\begin{array}{l}\text { Brand } \\
\text { loyalty }\end{array}$} & -0.025 & 0.155 & -0.404 & Not Supported \\
\hline $\begin{array}{c}\text { EM \& Enticing benefit } \\
(\mathrm{H} 3 \mathrm{~b})\end{array}$ & $\rightarrow$ & & -0.099 & 0.145 & -1.383 & Not Supported \\
\hline $\begin{array}{c}\text { SV \& Symbolic benefit } \\
(\mathrm{H} 3 \mathrm{c})\end{array}$ & $\rightarrow$ & & 0.065 & 0.129 & 0.857 & Not Supported \\
\hline $\begin{array}{c}\text { EV \& Socially responsible } \\
\text { benefit }(\mathrm{H} 3 \mathrm{~d})\end{array}$ & & & -0.054 & 0.068 & -0.931 & Not Supported \\
\hline Brand identification $(\mathrm{H} 4)$ & $\rightarrow$ & Brand trust & 0.688 & 0.051 & $10.737^{* * *}$ & Supported \\
\hline Brand identification (H5) & $\rightarrow$ & Brand loyalty & 0.409 & 0.066 & $4.654^{* * *}$ & Supported \\
\hline Brand trust (H6) & $\rightarrow$ & Brand loyalty & 0.467 & 0.094 & $4.628^{* * * *}$ & Supported \\
\hline Model fit & \multicolumn{6}{|c|}{$\mathrm{CMIN} / \mathrm{df}=1.567(\mathrm{p}<.001), \mathrm{CFI}=0.953, \mathrm{IFI}=0.954, \mathrm{TLI}=0.944, \mathrm{RMSEA}=0.038$} \\
\hline
\end{tabular}

with an absolute difference model. Thus, the closer the value of the consumption value to the perceived brand benefit, the closer this got to zero.

\subsubsection{The effect of congruity on brand identification, brand trust, and brand loyalty}

The effect of congruence between consumption value and perceived brand benefit on brand 
identification was examined (H1). The congruence between functional value and perceived enabling benefit, and the ethical value and perceived socially responsible benefit had significant positive influence on brand identification. However, the congruence between emotional value and perceived enticing benefit, and the social value and perceived symbolic benefit had no significant effect on brand identification.

Regarding congruence between consumption value and perceived brand benefit on brand trust (H2), congruity of functional value and perceived enabling benefit and ethical value and perceived socially responsible benefit had a significant effect. The effects of congruence between emotional value and perceived enticing benefit and social value and perceived symbolic benefit on brand trust were not statistically significant.

Congruence between consumption value and perceived brand benefit did not affect brand loyalty directly (H3). Thus, H3 was rejected.

\subsubsection{The Effect of Brand Identification on Brand Trust and Brand Loyalty, and the Effect of Brand Trust on Brand Loyalty}

Brand identification was found to affect brand trust. Brand trust consists of cognitive and affective beliefs, and it can be formed by brand identification though affective bonding. This confirms the results of Choi (2008), in which brand trust was influenced by an affective process, not a simple cognitive information process.

Brand identification affected brand loyalty. In a previous study, the effects of brand identification on brand loyalty were blended. Stokbuger-Sauer et al. (2012) stated that brand identification is a critical variable for brand loyalty. However, Kim et al. (2001) argued that brand identification has significant effects on word-of-mouth intentions even though it has no effects on brand loyalty. This study confirmed that brand identification has significant effects on brand loyalty.

Brand trust was found to affect brand loyalty. This was consistent with Morgan and Hunt (1994), who found that brand trust affects brand loyalty and commitment.

\section{Findings}

As the number of consumers who are willing to express their values through consumption increases, new patterns of behavior such as good consumption and value consumption increase. After passing through a product-oriented market and a consumer-oriented market, we now live in the Market 3.0 era, which is value driven (Kotler, 2010). The core concept of the Market 3.0 era is value. Recently, consumer behavior patterns have changed: consumers want to express their values and lead change through 
consumption. Therefore, in this study, we looked at the impact of consumption value, which is the criterion that most influences consumers' choice of behavior, on brand loyalty when it matches brand benefits, along with the mediated effects of brand identification and brand trust. Marketing research has studied the effect of congruence between self-concept and brand image on brand identification. Previous studies focused on the functions of products or services or the affective aspect of brands. This study expanded the marketing field by researching a broader area, including ethical values that are important for recent consumers. Among the four types of congruence between consumption values and perceived brand benefits, congruence between the functional value and perceived enabling benefit and the ethical value and perceived socially responsible benefit had a significantly positive effect on brand identification and brand trust. This is consistent with Park et al. (2016)'s research which insisted that brands can be trusted when they provide enabling benefits that benefits from the functions or objective qualities of the goods, which is related to consumers' functional value.

This study also confirmed that congruence between the functional value and perceived enabling benefit and the ethical value and perceived socially responsible benefit had a positive effect on brand loyalty by mediating brand identification and brand trust. However, significant effect was not found in the congruence between emotional value and perceived enticing benefit, and the social value and perceived symbolic benefit. Most of the brands that respondents reported were reasonably priced fashion brands such as Nike, Adidas, Zara, etc. They may have a much weaker effect on brand identification, brand trust and brand loyalty than luxury brands that have much stronger enticing and symbolic benefits.

Second, congruence between consumption value and perceived brand benefits did not have a direct effect on brand loyalty. However, this was found to have a positive influence by mediating brand identification and brand trust. Therefore, congruence between consumption values and perceived brand benefits can influence brand loyalty through brand identification and brand trust. This confirmed the research of Kuenzel and Halliday (2008), that brand identification plays an important role in consumers' brand loyalty, and of Reichheld (2003), who found that consumers recommend a brand when they have trust in the brand.

Finally, brand identification and brand trust were found to have a positive effect on brand loyalty. Brand identification had a direct effect on brand loyalty, and it was found to have a positive effect on brand loyalty by mediating brand trust. In other words, in order to increase brand loyalty, consumers need to identify or trust the brand. Brand loyalty is an important variable in the marketing field. In order to build brand loyalty, consumers must identify 
with the brand or build trust in the brand. This means that brand identification increases as consumer values and brand benefits match, which can lead to high trust in the brand.

\section{Discussion}

This study identified variables affecting brand loyalty, which is an important factor in building strong customer-based brand equity. Brand identification and brand trust play a key role in forming brand loyalty and brand equity. By examining the congruence of consumption values and brand benefits as leading variables that can influence brand identification and trust, the study yields theoretical contributions and practical implications. First, this study comprehensively researched consumption values, including ethical aspects, because consumers have become increasingly interested in consumption that has social ripple effects. Second, this study examined how consumption values can influence decisions to select and build relationships with brands. Third, this study provides a basis for implementing a marketing strategy to build brand assets and increase brand loyalty by providing consumers with the values they want in a diversified market.

The limitations of this study and directions for future study are as follows. The sample used in this study was relatively large in the
20 - 30 age range. Therefore, it is necessary to verify various age groups in future studies, which would contribute to the expansion of consumption value research by analyzing the difference in its influence among age groups. Second, in this study, the purchasing category of respondents was limited to fashion; it would be meaningful to expand future studies to other categories and examine the differences among them.

〈Received January 3. 2021〉

〈Accepted February 2. 2021〉

\section{References}

Aaker, D. A. (1996). Building Strong Brand. New York: The Free Press.

Aaker, J. L. (1997). Dimensions of brand personality. Journal of Marketing Research, 34(3), 347-356.

Ahearne, M., Bhattacharya, C. B., \& Gruen, T. (2005). Antecedents and consequences of customer-company identification: Expanding the role of relationship marketing. Journal of Applied Psychology, 90(3), 574-585.

Allen, C. T., Fournier, S., \& Miller, F. (2008). Brands and their meaning makers. In Haugtvedt, C. P., Herr, P. M., \& Kardes, F. R. (Eds). Handbook of Consumer Psychology (pp. 781-822). New York: Routledge. 
Allen, M. W., Ng, S. H., \& Wilson, M. (2002). A functional approach to instrumental and terminal values and the value-attitudebehaviour system of consumer choice. European Journal of Marketing, 36(1/2), 111-135.

Arnott, D. C., Wilson, D., Elliott, R., \& Yannopoulou, N. (2007). The nature of trust in brands: a psychosocial model. European Journal of Marketing, 41(9/10), 988-998.

Badrinarayanan, V., \& Laverie, D. A. (2011). Brand advocacy and sales effort by retail salespeople: Antecedents and influence of identification with manufacturers' brands. Journal of Personal Selling \& Sales Management, 31(2), 123-140.

Bagozzi, R. P., \& Dholakia, U. M. (2006). Antecedents and purchase consequences of customer participation in small group brand communities. International Journal of Research in Marketing, 23(1), 45-61.

Bang, J. H., Jung, J. Y., Lee, E. H., \& Kang, H. M. (2010). An exploratory study on the effects of relational benefits and brand identity: mediating effect of brand identity. Asia Marketing Journal, 12(2), 155-175.

Becerra, E. P., \& Badrinarayanan, V. (2013). The influence of brand trust and brand identification on brand evangelism. Journal of Product \& Brand Management, 22(5/6), 371-383.

Becerra, E. P., \& Korgaonkar, P. K. (2011). Effects of trust beliefs on consumers' online intentions. European Journal of Marketing, 45(6), 936-962.

Bhattacharya, C. B., \& Sen, S. (2003). Consumercompany identification: A framework for understanding consumers' relationships with companies. Journal of Marketing, 67(2), 76-88.

Bloch, M., \& Barros. J. (2011). Physical-layer security: From information theory to security engineering. Cambridge University Press.

Boksberger, P. E., \& Melsen, L. (2011). Perceived value: A critical examination of definitions, concepts and measures for the service industry. Journal of Services Marketing, 25(3), 229-240.

Brewer, M. B. (1979). In-group bias in the minimal intergroup situation: A cognitivemotivational analysis. Psychological Bulletin, 86(2), 307.

Byrne, B. M. (2013). Structural equation modeling with Mplus: Basic concepts, applications, and programming. routledge.

Chaudhuri, A., \& Holbrook, M. B. (2001). The chain of effects from brand trust and brand affect to brand performance: The role of brand loyalty. Journal of Marketing, 65(2), 81-93.

Choi, M. W., \& Cho, B. L. (2005). A study of the brand relationship quality: with focus on the relation with the components of brand equity. The Korean Journal of Advertising and Public Relations, 7(4), 
127-168.

Choi, S. H. (2008). The role of brand trust in the formation of a consumer-brand relationship. The Korean Journal of Advertising, 19(5), 75-96.

De Chernatony, L., \& McDonald, M. (2003). Creating powerful brands in consumer service and industrial markets ( $2^{\text {nd }}$ ed.). Biddles.

Delgado-Ballester, E., \& Munuera-Alemán, J. L. (2005). Does brand trust matter to brand equity? Journal of Product \& Brand Management, 14(3), 187-196.

Delgado-Ballester, E., \& Munuera-Alemán, J. L., \& Yague-Guillen, M. J. (2003). Development and validation of a brand trust scale. International Journal of Market Research, 45(1), 35-54.

Dunn, J. R., \& Schweitzer, M. E. (2005). Feeling and believing: the influence of emotion on trust. Journal of Personality and Social Psychology, 88(5), 736.

Edwards, J. R., \& Cale, D. M. (2009). The value of value congruence. Journal of Applied Psychology, 94(3), 654-677.

Elbedweigy, A. M., Jauawardhena, C., Elasharnouby, M. H., \& Elasharnouby, T. H. (2016). Customer relationship building: The role of brand attractiveness and consumer-brand identification. Journal of Business Research, 26(8), 2901-2910.

Embrain Trend Monitor. (2019). The most common activity, consumption: Can society change with good consumption, which is highly sympathetic to consumers? https:// trendmonitor.co.kr/tmweb/trend/allTrend /detail.do? bIdx $=1824 \&$ code $=0404 \&$ trend Type $=$ CKOREA

Escalas, J. E., \& Bettman, J. R. (2003). You are what they eat: The influence of reference groups on consumers' connections to brands. Journal of Consumer Psychology, 13(3), 339-348.

Fournier, S. (1998). Consumers and their brands: Developing relationship theory in consumer research. Journal of Consumer Research, 24(4), 343-373.

Fournier, S. (2009). Lessons learned about consumers' relationships with their brands. In D. J. MacInnis, C. W. Park, \& J. R. Priester (Eds.), Handbook of Brand Relationships (pp. 5-23). M.E. Sharpe.

Freitag. (n.d.). The Freitag Story. https:// www.freitag.ch/ko/about

Garbarino, E., \& Johnson, M. S. (1999). The different roles of satisfaction, trust, and commitment in customer relationships. Journal of Marketing, 63(2), 70-87.

Gummerus, J. (2013). Value creation processes and value outcomes in marketing theory: Strangers or siblings? Marketing Theory, 13(1), 19-46.

Gwinner, K. P., Gremler, D. D., \& Bitner, M. J. (1998). Relational benefits in services industries: The customer's perspective. Journal of the Academy of Marketing 
Science, 26(2), 101-114.

Hamilton, M., \& Sun, X. (2005). Actual self and ideal brand image: An application of selfcongruity to brand image positioning [Paper presentation]. International Communication Association Annual Meeting, New York, NY, United States.

He, H., \& Li, Y. (2011). CSR and service brand: The mediating effect of brand identification and moderating effect of service quality. Journal of Business Ethics, 100(4), 673-688.

Hoffmann, S., \& Soyez, K. (2010). A cognitive model to predict domain-specific consumer innovativeness. Journal of Business Research, 63(7), 778-785.

Holbrook, M. B., \& Hirschman, E. C. (1982). The experiential aspects of consumption: Consumer fantasies, feelings, and fun. Journal of Consumer Research, 9(2), 132140.

Holbrook, M. B. (1999). Consumer Value: A Framework for Analysis and Research. Psychology Press.

Holbrook, M. B. (2006). Consumption experience, customer value, and subjective personal introspection: An illustrative photographic essay. Journal of Business Research, 59(6), 714-725.

Johar, J. S., \& Sirgy, M. J. (1991). Valueexpressive versus utilitarian advertising appeals: When and why to use which appeal. Journal of Advertising, 20(3), 23-33.
Keh, H. T., \& Xie, Y. (2009). Corporate reputation and customer behavioral intentions: The roles of trust, identification, and commitment. Industrial Marketing Management, 38(7), 732-742.

Keller, K. L. (1993). Conceptualizing, measuring, and managing customer-based brand equity. Journal of Marketing, 57(1), 1-22.

Khamitov, M., Wang, X., \& Thomson, M. (2019). How well do consumer-brand relationships drive customer brand loyalty? Generalizations from a meta-analysis of brand relationship elasticities. Journal of Consumer Research, 46(3), 435-459.

Kim, C. K., Han, D., \& Park, S. B. (2001). The effect of brand personality and brand identification on brand loyalty: Applying the theory of social identification. Japanese Psychological Research, 43(4), 195-206.

Kim, H. R., Lee, M. K., \& Kim, N. (2005). Determinants and consequences of the brand attachment. Journal of Consumer Studies, 16(3), 45-65.

Kim, R. D., Jeon, M. Y., Lee, H. E., Lee, J. Y., Kim, S. Y., Seo, Y. H., \& Lee, S. J. (2017). Trend Korea 2018. MiraeBook.

Kim, R. D., Jeon, M. Y., Lee, S. E., Lee, J. Y., Kim, S. Y., Choi, J. H., Lee, S. J., Seo, Y. H., \& Kwon, J. (2018). Trend Korea 2019. MiraeBook.

Kim, R. D., Jeon, M. Y., Choi, J. H., Lee, H. E., Lee, J. Y., Kim, S. Y., Lee, S. J., Seo, Y. H., \& Kwon, J. Y. (2019). Trend Korea 
2020. MiraeBook.

Koo, M. J., Kim, R. D., Kim, S. Y., Rha, J. Y., Yeo, J. S., \& Choe, H. C. (2015). Measuring and mapping consumption values. Journal of Consumer Studies, 26(6), 235-264.

Kotler, P., Kartajaya, H., \& Setiawan, I. (2010). Marketing 3.0: From Products to Customers to the Human. Wiley.

Kramer, R. M., Brewer, M. B., \& Hanna, B. A. (1996). Collective trust and collective action. Trust in organizations: Frontiers of theory and research, 357-389.

Kressmann, F., Sirgy, M. J., Herrmann, A., Huber, F., Huber, S., \& Lee, D. J. (2006). Direct and indirect effects of self-image congruence on brand loyalty. Journal of Business Research, 59(9), 995-964.

Kuenzel, S., \& Halliday, S. V. (2008). Investigating antecedents and consequences of brand identification. Journal of Product and Brand Management, 17(5), 293-304.

Kyriazos, T. A. (2018). Applied psychometrics: sample size and sample power considerations in factor analysis (EFA, CFA) and SEM in general. Psychology, 9(08), 2207-2230.

Lam, S. K., Ahearne, M., \& Schillewaert, N. (2012). A multinational examination of the symbolic-instrumental framework of consumer-brand identification. Journal of International Business Studies, 43(3), 306331.

Lee, H. J. (2005). The impact of congruence between brand personality and self-image on brand loyalty: The mediating roles of brand identification and brand attachment [Unpublished master's thesis]. Ewha Womans University.

Lee, K. H., \& Jeong, G. Y. (2016). A study on the effect of overall brand experiences on emotional consumption value and brand identification: focused on color cosmetics brands. Journal of Product Research, 34, 41-53.

Malar, L., Krohmer, H., Hoyer, W. D., \& Nyffenegger, B. (2011). Emotional brand attachment and brand personality: The relative importance of the actual and the ideal self. Journal of Marketing, 75(4), 35-52.

Martínez, P., \& Rodríguez del Bosque, I. (2013). CSR and customer loyalty: The roles of trust, customer identification with the company and satisfaction. International Journal of Hospitality Management, 35, 89-99.

MBN (n.d.). Daily economic glossary: Good consumption. https://www.mk.co.kr dic/ desc.php?keyword = \%C2\%F8\%C7\%D1\% $\mathrm{BC} \% \mathrm{D} 2 \% \mathrm{BA} \% \mathrm{~F} 1 \&$ page $=0 \& \mathrm{so}=$ all \&from $=\& t_{0}=$.

Mimouni-Chaabane, A., \& Volle, P. (2010). Perceived benefits of loyalty programs: Scale development and implications for relational strategies. Journal of Business Research, 63(1), 32-37.

Morar, D. D. (2013). An overview of the 
consumer value literature: Perceived value, desired value. Marketing from Information to Decision, 6, 169-186.

Morgan, R. M., \& Hunt, S. D. (1994). The commitment-trust theory of relationship marketing. Journal of Marketing, 58(3), 20-38.

Morgan, R. M., \& Hunt, S. D. (1999). Relationshipbased competitive advantage: The role of relationship marketing in marketing strategy. Journal of Business Research, 46(3), 281290.

Nam, J., Ekinci, Y., \& Whyatt, G. (2011). Brand equity, brand loyalty and consumer satisfaction. Annals of Tourism Research, 38(3), 1009-1030.

Nam, S. (2007). The effects of individualism/ collectivism and consumption values on consumption self-regulation. Journal of Consumption Culture, 10(3), 59-86.

Papista, E., \& Krystallis, A. (2013). Investigating the types of value and cost of green brands: Proposition of a conceptual framework. Journal of Business Ethics, 115(1), 75-92.

Park, C.W., Jaworsk, B.J., \& MacInnis, D.J. (1986). Strategic brand concept-image management. Journal of Marketing, 50(4), 135-145.

Park, C. W., MacInnis, D. J., \& Eisingerich, A. B. (2016). Brand Admiration: Building a Business People Love. John Wiley \& Sons. Park, C. W., MacInnis, D. J., Priester, J., Eisingerich, A. B., \& Iacobucci, D. (2010).
Brand attachment and brand attitude strength: Conceptual and empirical differentiation of two critical brand equity drivers. Journal of Marketing, 74(6), 1-17.

Park, J. Y. (2018). Effect of consumption values on the sharing economy: Interaction effect of psychological ownership motivation [Unpublished master's thesis]. Ewha Womans University.

Park, B. J., \& Kim, S. W. (2006). A study on the consumption value, brand identification, consumer-brand relationship of KoreanJapanese university consumers: Focused on the famous brand. Journal of Consumer Studies, 17(4), 113-143.

Park, S. Y., \& Lee, E. M. (2005). Congruence between brand personality and self-image, and the mediating roles of satisfaction and consumer-brand relationship on brand loyalty. Asia Pacific Advances in Consumer Research, 6, 39-45.

Park, S. Y., \& Lee, H. J. (2009). Mediating roles of brand identification and brand attachment in the model of the influence of congruence between brand personality and self-image on brand loyalty. Journal of Consumption Culture, 12(2), 19-37.

Park, S. Y., \& Lee, Y. K. (2006). Effect of the congruence between brand personality and self-image on customer satisfaction, consumer-brand relationship and brand loyalty in Korean culture. The Korean Journal of Advertising, 17(1), 7-24. 
Park, S. Y., \& Yu, S. L. (2003). Customerbrand relationship (CBR): The Influence of CBR on customer satisfaction and brand loyalty. Journal of New Industry and Business, 21(1), 23-45.

Quaak, L., Aalbers, T., \& Goedee, J. (2007). Transparency of corporate social responsibility in Dutch breweries. Journal of Business Ethics, 76(3), 293-308.

Regional Regulatory Innovation Division. (2020). Good consumption saves the local economy! A campaign to promote of emergency disaster support funds with local governments. Ministry of Interior and Safety https://www.mois.go.kr/frt/bbs/type010/ commonSelectBoard Article.do?bbsId = BBSMSTR_000000000008\&nttId $=77384$

Reichheld, F. F. (2003). The one number you need to grow. Harvard Business Review, 81(12), 46-55.

Rokeach, M. (1979). From individual to institutional values: With special reference to the values of science. Understanding Human Values, 47, 70 .

Sanchez-Fernandez, R., Angeles Iniesta-Bonillo, M., \& Holbrook, M. B. (2009). The conceptualization and measurement of consumer value in services. International Journal of Market Research, 51(1), 93-113.

Seo, S. H. (2016). The influence of brand storytelling types on the structural relationships among brand consciousness, brand identification, image elaboration, brand image, attitude toward brand. Advertising Research, 108, 31-63.

Sheth, J. N., Newman, B. I., \& Gross, B. L. (1991). Why we buy what we buy: A theory of consumption values. Journal of Business Research, 22(2), 159-170.

Shim, H. J. (2019). The effects of brand benefits and self-brands connections on brand loyalty: Focusing on mediating effect of brand attachment. The Korean-Japanese Journal of Economics and Management Studies, 83, 45-72.

Sirgy, M. J. (1982). Self-concept in consumer behavior: A critical review. Journal of Consumer Research, 9(3), 287-300.

Smit, E., Bronner, F., \& Tolboom, M. (2007). Brand relationship quality and its value for personal contact. Journal of Business Research, 60(6), 627-633.

Stenn, T. (2013), The Cultural and Political Intersection of Fair Trade and Justice, 29-47, Palgrave Macmillan

Stokburger-Sauer, N., Ratneshwar, S., \& Sen, S. (2012). Drivers of consumer-brand identification. International Journal of Research in Marketing, 29(4), 406-418.

Sweeney, J. C., \& Soutar, G. N. (2001). Consumer perceived value: The development of multiple item scale. Journal of Retailing, 77(2), 203-220.

Tajfel, H. (1981). Human Groups and Social Categories: Studies in Social Psychology. Cambridge University Press. 
Tuskej, U., Golob, U., \& Podnar, K (2013). The role of consumer-brand identification in building brand relationship. Journal of Business Research, 66(1), 53-59.

Underwood, R., Bond, E., \& Baer, R. (2001). Building service brands via social identity: Lessons from the sports marketplace. Journal of Marketing Theory and Practice, 9(1), 1-13.

University Tomorrow 20's Lab. (2019). Millennials- $Z$ generation trend keyword. https://www.20slab.org/Archives/37201

Williams, M. (2001). In whom we trust: Group membership as an affective context for trust development. Academy of Management
Review, 26(3), 377-396.

Won, J. H., \& Chung, J. E. (2015). The segmentation of single-person households based on Sheth's theory of consumption values. Journal of Consumer Studies, 26 (1), 73-99.

Yi, Y. J., \& La, S. A. (2002). Brand personalitybrand identification-brand equity model: An exploratory study on the difference between users vs. non-users. Korean Marketing Review, 17(3), 1-33.

Zeithaml, V. A. (1988). Consumer perceptions of price, quality, and value: A means-end model and synthesis of evidence. Journal of Marketing, 52(3), 2-22. 